\title{
A Debatable Top Ten Papers in Geriatric Medicine List
}

\author{
David B. Hogan, md, frcpc \\ Division of Geriatric Medicine, Department of Medicine, Cumming School of Medicine, \\ University of Calgary, Calgary, $A B$
}

https://doi.org/10.5770/cgj.23.440

\begin{abstract}
A personal top ten list of literature about aging and the practice of geriatrics is offered. This is primarily directed at those completing their training in the care of older patients. While acknowledging the limitations of any such exercise, it is hoped that it will engender interest in prior work by and about older persons and their care. Those at the start of their careers in geriatrics are encouraged to read these and other primary contributions, make their own list of essential literature, and incorporate the lessons learned and the examples of prior practitioners into their professional practice.
\end{abstract}

Key words: geriatrics, literature, professional practice

\section{INTRODUCTION}

When approached about giving a talk on the top ten papers of all time in geriatric medicine for the Resident Education Day at the 2020 Annual Scientific Meeting of the Canadian Geriatrics Society, I quickly agreed. Aside from the intrinsic interest of the topic, it also represented an opportunity to introduce a new generation to some of the hard-won lessons of the past. Others have published on work they felt represented significant contributions to the care of older persons, ${ }^{(1,2)}$ but not for this particular audience. Although about children and not young professionals, Plato (429?-347 B.C.E.) wrote in The Republic:

"... the beginning is the most important part ... for that is the time at which the character is being formed and the desired impression is more readily taken ... Anything received into the mind at that age is likely to become indelible and unalterable." (excerpt from Book II—Dialogue between Socrates and Adeimantus)

\section{METHODS}

I considered original works (books and essays) written by older persons or papers about their care. This is not a systematic review of the literature, but rather a selection of contributions known to me that I judged noteworthy. Those by Canadians are unapologetically highlighted. I excluded anything published in the last ten years (to allow sufficient time for impressions to solidify), work I authored, and general guidance on how to age well (sorry Deepak Chopra).

As a framework, I first considered foundation papers of the discipline and then those that aligned with the geriatric $5 \mathrm{Ms},{ }^{(3,4)}$ a recent attempt of the Canadian Geriatrics Society to concisely describe the field. Similar efforts date back to the 1960s when the Geriatric Giants (or the four I's of impaired intellect, incontinence, immobility, and instability [falls]) were proposed by Bernard Isaac. ${ }^{(5)}$ My top ten ${ }^{(6-15)}$ (see Table 1) was selected from 44 shortlisted papers. ${ }^{(6-49)}$ While the papers are not ranked, I included the number of Google Scholar citations (January 28, 2020) for shortlisted papers, more to demonstrate the limitations of this particular bibliometric than to trumpet its virtues.

The major limitation of this exercise is the biases that arise from selections being made by one person. My choices are idiosyncratic, subject to a variety of conscious and unconscious influences. I also restricted my choices to English language publications that aligned with the categories noted above. This led to the omission of excellent papers on incontinence, medical education, and the design of health-care systems for older persons, to name but a few neglected areas. As a last word on my methodology, I defer to the Rev. Jonathan Swift (1667-1745):

\begin{abstract}
“'That was excellently observed,' say I, when I read a passage in an author, where his opinion agrees with mine. When we differ, there I pronounce him to be mistaken." (The Works of the Rev. Jonathan Swift, Volume 5)
\end{abstract}

\section{TOP TEN}

\section{Foundation of the Discipline}

While Ignatz Nascher (1863-1944) coined the word "geriatrics", (50) Marjory Warren (1897-1960) founded the discipline. (51) Two of her papers, ${ }^{(6,16)}$ and the BMA Committee on the Care and Treatment of the Elderly report ${ }^{(17)}$ she co-authored, 
TABLE 1.

Top ten selections

\section{Foundation of the Discipline}

- Warren MW. Care of chronic sick. ${ }^{(6)}$ (172 Google Scholar citations)

- Rubenstein LZ, Josephson KR, Wieland GD, et al. Effectiveness of a geriatric evaluation unit - a randomized controlled trial. $^{(7)}$ (1060 citations)

Matters Most

- Athill D. Somewhere towards the end. ${ }^{(8)}$

Mind

- Kral VA. Senescent forgetfulness: benign and malignant. ${ }^{(9)}$ (911 citations)

- Inouye SK, van Dyck CH, Alessi CA, et al. Clarifying confusion: the confusion assessment method. A new method for detection of delirium. ${ }^{(10)}$ (4317 citations)

- Katzman R. Editorial: The prevalence and malignancy of Alzheimer disease: a major killer. ${ }^{(11)}$ (880 citations)

Mobility

- Tinetti ME, Baker DI, McAvay G, Claus EB, Garrett P, et al. A multifactorial intervention to reduce the risk of falling among elderly people living in the community. ${ }^{(12)}$ (2611 citations)

- Podsiadlo, D, Richardson S. The timed "Up \& Go": a test of basic functional mobility for frail elderly persons. (13) (11076 citations)

\section{Medications}

- Beers MH, Ouslander JG, Rollingher I, et al. Explicit criteria for determining inappropriate medication use in nursing home residents. ${ }^{(14)}$ (1673 citations)

Multi-complexity

- Rockwood K, Fox RA, Stolee P, Robertson D, et al. Frailty in elderly people: an evolving concept. ${ }^{(15)}$ (674 citations)

made the initial case for it. I selected her 1943 BMJ paper ${ }^{(6)}$ as one of my top ten.

While not ascribing to the belief that things only count if they can be counted, the accurate measurement of critical patient characteristics is key to practice. This includes assessing basic and instrumental activities of daily living with standardized tools like those developed by Sidney Katz (1924-2012) $^{(18,52)}$ and M. Powell Lawton (1923-2001). ${ }^{(19,53)}$

The report of the 1987 National Institutes of Health (NIH) consensus meeting on comprehensive geriatric assessment (CGA) ${ }^{(20,54,55)}$ made explicit the components of this then "new technology"(56) that remains our most reliable intervention for high need patients. ${ }^{(57)}$ I picked Rubenstein's positive geriatric evaluation unit trial( ${ }^{(7)}$ as one of the top ten for its timely support of the utility of both CGA and the field. The importance of recognizing and creating strategies to minimize the adverse impacts of hospitalization on older persons go back to Warren. ${ }^{(21,22)}$

The final papers cover the contrasting manner age-related population health has been perceived. ${ }^{(23-26)}$ At one extreme is the conviction that older people saved from an early death will live through prolonged periods of disability, isolation, and neglect (expansion of morbidity). ${ }^{(23,25,58)}$ At the other end is the hopeful belief that at least, for some, we can extend good health quicker than life expectancy ${ }^{(24,26)}$ and, as Ashley Montagu (1905-1999) put it, "die young as late as possible" (compression of morbidity). How our future will actually unfold remains unsettled. ${ }^{(59)}$

\section{The Geriatric 5Ms}

\section{A. Matters Most}

While papers on self-rated health, ${ }^{(27)}$ quality of life, ${ }^{(28)}$ and advance care planning ${ }^{(29)}$ are included, my focus are the observations and recommendations of older person. ${ }^{(8,30-32)}$ Cato Maior De Senectute by Marcus Tullius Cicero (January 3, 106 BC-December 7, 43 BC) was not chosen. Written by Cicero when he was 62, it is a fictional discourse between the 84-year old Cato and two younger Romans that refutes four common complaints about growing old (withdrawal from active life, enfeeblement, loss of enjoyment, and the approach of death). Cicero hoped he was correct, but his assassination the next year prevented him from testing the validity of his arguments. The octogenarian Malcolm Cowley wrote, “... a great deal has been written about old age, but most of the authors ... [are] in their late fifties or early sixties. They knew the literature but not the life." ${ }^{(60)}$ I stuck to the voices of lived experience.

The glum piece by Stephen Leacock (1869-1944), paradoxically best known as one of our country's greatest humourists, uses walking into no man's land and falling one-by-one as a metaphor for old age. ${ }^{(30)}$ Written in his seventy-first year, an extensively revised and more hopeful version appeared two years later in a collection of his essays. ${ }^{(61)}$ The contribution by Bertrand Russell (1872-1970) was originally published when he was 78 and provides advice on aging in an elegant, though ethereal, manner. ${ }^{(31)}$ Malcolm Cowley (1898-1989) wrote about his life after turning 80 , providing a realistic appraisal of both the good and bad aspects. ${ }^{(32)}$ A few years later, when 86 , he offered further observations that included detailed directions on how to pull on your pants. ${ }^{(62)}$ The book by Diana Athill (1917-2019), a writer noted for her candour, is my choice for this section. ${ }^{(8)}$ Without the comfort of religion, children, or wealth, she faced potential infirmity and death buttressed by her ability to adapt, not regret, maintain relationships, and stay engaged in life. Any geriatrician reading about her reluctance to stop driving notwithstanding four accidents the previous year will experience déjà vu. While each of these authors should be read in the whole, Table 2 provides selected quotes to give you a sense of their thinking.

\section{B. Mind}

The two cognitive instruments shortlisted ${ }^{(33,34)}$ were (and are) widely used to assess older patients for mild cognitive impairment $(\mathrm{MCI})^{(38)}$ and dementia. The original description of the Mini-Mental State Examination ${ }^{(33)}$ is the most-cited psychiatric paper of all time. ${ }^{(63)}$

The 1962 publication of V. A. Kral (1903-1988), describing what he called benign senescent forgetfulness (BSF), is one of my top ten. ${ }^{(9,64)}$ Marked by an inability of "wellpreserved" older persons to consistently recall "unimportant 
TABLE 2.

Selected quotes about growing old.

Stephen Leacock ${ }^{(30)}$

- "For the reality of life, we learn too late, it is in the living tissue of it from day to day, not in the expectation of better, nor in the fear of worse." (Page 72)

Bertrand Russell ${ }^{(31)}$

- "If you have wide and keen interests and activities in which you can still be effective, you will have no reason to think about the merely statistical fact of the number of years you have already lived, still less of the probable brevity of your future ... Psychologically there are two dangers to be guarded against in old age. One of these is undue absorption in the past ... thoughts must be directed to the future, and to things about which there is something to be done ... The other thing to be avoided is clinging to youth in the hope of sucking vigour from its vitality." (Page 50-51)

- "The best way to overcome [fear of death] ... is to make your interests gradually wider and more impersonal, until bit by bit the walls of the ego recede, and your life becomes increasingly merged in the universal life. An individual human existence should be like a river - small at first, narrowly contained within its banks, and rushing passionately past boulders and over waterfalls. Gradually the river grows wider, the banks recede, the waters flow more quietly, and in the end, without any visible break, they become merged in the sea, and painlessly lose their individual being ... I would wish to die while still at work, knowing others will carry on what I can no longer do, and content in the thought that what was possible has been done." (Page 52)

Malcolm Cowley ${ }^{(32)}$

- Among examples of receiving the message "You are old" he included when "[the older person] can't stand on one leg and has trouble pulling on his pants ... [and] hesitates on the landing before walking down a flight of stairs." (Page 3-4)

- "[Gerontologists say] 'Put cotton in your ears and pebbles in your shoes ... there you have it: instant aging.' Not quite ... [as] omits the messages from the social world ... We start by growing old in other people's eyes, then slowly we come to share their judgment." (Page 5)

- "A growing weakness of American society is that it regards the old as consumers but not producers, as mouths but not hands." (Page 37)

- “... every old person needs a work project if he wants to keep himself more alive.” (Page 67)

Diana Athill( ${ }^{(8)}$

- ' 'I am not afraid of death.' My mother said this ... I believe the same is true of myself - but there are words which follow that statement so often that they have become a cliché: 'It's dying that I'm afraid of." (Page 60)

- "How successfully one manages to get through the present depends a good deal more on luck than it does on one's own efforts ... I can speak only for, and to, the lucky." (Page 171)

data", BSF was felt to progress slowly. ${ }^{(9)}$ Kral speculated it arose from milder degrees of the pathological processes leading to dementia. ${ }^{(9)}$ More severe cases of BSF (referred to as incipient amnestic syndrome) were similar to what we now call MCI. ${ }^{(38,64)}$

The work led by Sharon Inouye ${ }^{(65)}$ on delirium moved logically from identification with the Confusion Assessment Method $^{(10)}$ (which quickly became widely used and adapted for a variety of settings and purposes), ${ }^{(66)}$ uncovering risk factors, ${ }^{(67,68)}$ and describing how to prevent it ${ }^{(36)}$ to disseminating these ideas as the Hospital Elder Life Program (HELP). ${ }^{69,70)}$ Martin Cole and Jane McCusker of Montréal made important contributions to managing delirium and making clear its guarded prognosis. ${ }^{(35,37)}$

My third selection here is a two-page editorial ${ }^{(11)}$ by Robert Katzman (1925-2008) ${ }^{(71)}$ published in 1976. Alzheimer disease $(\mathrm{AD})$ was then considered a rare condition affecting those aged $<65$. Katzman argued that $A D$, and what was called senile dementia, were a single disease. A year later, the National Institute on Aging (NIA), National Institute of Neurological and Communicative Disorders and Stroke (NINCDS), and the National Institute of Mental Health (NIMH) co-sponsored a workshop on AD that concluded most patients with senile dementia had the same pathological changes as younger ones with $\mathrm{AD},{ }^{(72)}$ dramatically increasing the number of affected individuals (approximately $97 \%$ of those fitting this expanded definition are 65+). ${ }^{(73)}$ Subsequently, the NIA assumed leadership within the NIH for AD research, the Alzheimer Association was founded, ${ }^{(74)}$ and research activity grew exponentially. In 1975 there were 42 PubMed papers on AD. By 2018, this had grown to 6,413. Katzman felt the editorial was "... my major contribution [to AD research]."(75)

In the 1970s, scopolamine was found to adversely affect memory. ${ }^{(76)}$ It then became clear that levels of choline acetyl transferase (an enzyme essential for the synthesis of acetylcholine) were low in the brains of persons dying with AD. (77) The cholinergic hypothesis ${ }^{(78)}$ arising from these and other observations led to attempts at enhancing central cholinergic function as a treatment for AD. The paper by William K. Summers $^{(39)}$ on the clinical effects of cholinesterase inhibition on $\mathrm{AD}$ (a strategy first proposed by Alex Comfort ${ }^{(79)}$ ) was important, but seriously flawed, work. Its appearance led to hope that a major breakthrough had taken place. While an accompanying editorial lauded the study as a "triumph for the scientific method", ${ }^{(80)}$ subsequent letters to the New England Journal of Medicine were critical. ${ }^{(81)}$ In 1991 the Journal published a special report about the paper, including their justification for the decision to publish, a summary of concerns uncovered by the FDA in an investigation of the study, and a response by the authors to the FDA. $\left.{ }^{82}\right)$ The publication did encourage further $\mathrm{AD}$ trials, and the controversy led to deliberations on how to define a meaningful response to cognitive enhancers. ${ }^{(83)}$ Eventually, three cholinesterase inhibitors were approved for the treatment of AD in our country.

\section{Mobility (including falls)}

J. H. Sheldon (1893-1972) was one of the first to write about the "liability of old people to tumble and often injure 
themselves". ${ }^{40)} \mathrm{B}$. Isaacs provided a vivid example of the dire consequences of falls, ${ }^{(41,84)}$ though as Nanette Nisbet $(1925-$ 2014) wrote, “... it would be an even worse disaster if fear of falling were regarded as a good reason to keep ... people in bed."(85) Cyril Gryfe performed important early Canadian work on the epidemiology of falls in institutions. ${ }^{86,87)}$ Mary Tinetti's program of research on falls ${ }^{(12,42,43,88,89)}$ followed similar steps to those noted for delirium. I selected the multifactorial fall prevention intervention ${ }^{(12)}$ she developed for inclusion in the top ten.

The various performance-based assessments of fall risk, lower extremity function, balance, and gait $(42,44,90)$ includes the timed "Up \& Go" (TUG) test. ${ }^{(13)}$ A modification of a pre-existing instrument ${ }^{(91)}$ that improved its reliability and practicality, the TUG is the most used test for evaluating basic mobility skills, and one of my top ten.

\section{Medications}

A well-known Osler (1849-1919) quotation comes from a speech given on the 22nd of February 1891 to local public officials and faculty in Baltimore. In it, he argued for more rational therapeutics ${ }^{(92)}$ and said, "A desire to take medicine is, perhaps, the great feature which distinguishes man from other animals", later noting that "... a little more exercise, a little less food, and a little less tobacco and alcohol, may possibly meet the indications of the case" rather than a prescription. ${ }^{(45)}$

Mark Beers (1954-2009) died much too early from the complications of diabetes. ${ }^{(93)}$ Various versions of the Beers criteria, ${ }^{(14)}$ other lists of potentially inappropriate medications, ${ }^{(94,95)}$ and consideration of the factors described by Holly Holmes (remaining life expectancy, time until benefit, goals of care, treatment targets) ${ }^{(46)}$ have informed recent work on deprescribing. ${ }^{(96,97)}$

\section{E. Multi-complexity (frailty)}

Surprisingly, in light of the current intense interest in late-life frailty, the development and wide use of explicit criteria for its identification is a relatively new phenomenon. I picked the 1994 Rockwood contribution ${ }^{(15)}$ on the concept of frailty as a top ten selection. I appreciated its consideration of both assets and deficits when deciding on frailty status. Assessing for assets and estimating resiliency ${ }^{(98)}$ have disappeared from most current approaches to frailty. ${ }^{(48,49)}$ The other papers shortlisted for this section are an early study on the potential benefits of exercise and diet for frailty, ${ }^{(47)}$ and two that present contrasting ways of thinking about and looking for frailty. ${ }^{(48,49)}$

\section{FINAL THOUGHTS}

Little overlap is present between my choices and those made by others engaged in a similar task. There was none between my top ten shown in Table 1 and the 17 "classic papers" selected by Pignolo ${ }^{(2)}$ (Table 3), while only seven papers appeared on both my shortlist and the 59 papers referenced by Morley in his highlights of the last 50 years of geriatrics. ${ }^{(1)} \mathrm{Of}$ course, part of the attraction of "best ever" lists is the endless debate they engender. I generally showed greater interest in
TABLE 3.

Seventeen classic papers in geriatric medicine ${ }^{(2)}$

- Fries JF. Aging, natural death, and the compression of morbidity. N Engl J Med. 1980;303(3):130-35.

- Warren M. The evolution of a geriatric unit. Geriatrics. 1948;3:42-50.

- Saunders C. Watch with me. Nurs Times. 1965;61(48):1615-17.

- Cherkasky M. Montefiore Hospital Home Care Program. Am J Pub Health. 1949;39:163-66.

- Libow LL. A fellowship in geriatric medicine. J Am Geriatr Soc. 1972;20:580-84.

- Palmore E. Facts on aging. Gerontologist. 1977;17:315-20.

- Alzheimer A. A peculiar disease of the cerebral cortex. Arch Neurol. 1969;21:109-10.

- Folstein MF, Folstein SE, McHugh PR. "Mini-mental state": a practical method for grading the cognitive state of patients for the clinician. J Psychiatr Res. 1975;12(3):189-98.

- Engel GL, Romano J. Delirium, a syndrome of cerebral insufficiency. J Chronic Dis. 1959;9:260-77.

- Tinetti ME, Inouye SK, Gill TM, et al. Shared risk factors for falls, incontinence, and functional dependence: unifying the approach to geriatric syndromes. JAMA. 1995;273:1348-53.

- Foley FEB. A self-retaining bag catheter for use as an indwelling catheter for constant drainage of the bladder. J Urol. 1937;38:140-43.

- Albright F, Bloomberg E, Smith PH. Post-menopausal osteoporosis. Trans Assoc Am Phys. 1940;55:298-305.

- Finucane TE, Christmas C, Travis K. Tube feeding in patients with advanced dementia: a review of evidence. JAMA. 1999;282:1365-70.

- Walter LC, Covinsky KE. Cancer screening in elderly patients: a framework for individualized decision making. JAMA. 2001;285:2750-56.

- Keefer CS, Parker F Jr, Myers WK, et al. Relationship between anatomic changes in the knee joint with advancing age and degenerative arthritis. Arch Intern Med. 1934;53:325-44.

- The National Pressure Ulcer Advisory Panel. Pressure ulcers prevalence, cost, and risk assessment: Consensus Development Conference Statement. Decubitus. 1989;2(2):24-28.

- Kraepelin E. I: Introduction: Melancholia. In: Kraepelin E, editor. Lectures on clinical psychiatry. New York, NY: William Wood; 1904. p. 4-10.

prototypes or preliminary models rather than the end products. Papers describing either how to accurately detect ${ }^{(10,14,38,48,49)}$ or quantify $(13,18,19,27,28,33,34,42,44)$ made up about a third of my shortlisted papers. These contributions tended to be the ones most cited, an observation noted in other fields. ${ }^{(63)}$ What doesn't appear as selections are cutting-edge biological discoveries or novel developments in the social sciences.

My choices were restricted by the boundaries of my training, practice, and research interests. The pieces selected were often the product of a substantial commitment to an area of research or practice that extended over years, if not decades. The passion, purpose, and strength of conviction, as well as scientific rigour the authors brought to their task, were evident. What they proposed often represented disruptive change and was contested. 


\section{ACKNOWLEDGEMENTS}

The author would like to thank his initial instructor in geriatrics, Dr. R. D. T. Cape, and all the authors noted here for their reflection on how to improve our lives during its latter half.

\section{CONFLICT OF INTEREST DISCLOSURES}

The authors declare that no conflicts of interest exist.

\section{REFERENCES}

1. Morley JE. Geriatrics: highlights of the Last 50 Years. $J$ Nutr Health Aging. 2019;23:910-13.

2. Pignolo RJ, Crane MK, Forciea MA. Classic papers in geriatric medicine with current commentaries. Totowa, NJ: Humana Press; 2008.

3. Tinetti M, Huang A, Molnar F. The Geriatrics 5M's: a new way of communicating what we do [letter to the editor]. $J \mathrm{Am}$ Geriatr Soc. 2017;65(9):2115.

4. Molnar F, Frank CC. Optimizing geriatric care with the GERIATRIC 5Ms. Can Fam Physician. 2019;65(1):39.

5. Isaacs B. Introduction to geriatrics. London, UK: Balliere, Tindall and Cassell; 1965.

6. Warren MW. Care of chronic sick. Br Med J. 1943;2(4329): 822-23. (172 Google Scholar citations)

7. Rubenstein LZ, Josephson KR, Wieland GD, et al. Effectiveness of a Geriatric Evaluation Unit - a randomized controlled trial. N Engl J Med. 1984;311:1664-70. (1060 citations)

8. Athill D. Somewhere towards the end: a memoir. London, UK: Granta; 2009.

9. Kral VA. Senescent forgetfulness: benign and malignant. CMAJ. 1962;86(6):257-60. (911 citations)

10. Inouye $\mathrm{SK}$, van Dyck $\mathrm{CH}$, Alessi $\mathrm{CA}$, et al. Clarifying confusion: the confusion assessment method. A new method for detection of delirium. Ann Intern Med. 1990;113(12):941-48. (4317 citations)

11. Katzman R. Editorial: The prevalence and malignancy of Alzheimer disease: a major killer. Arch Neurol. 1976;33(4):217-18. (880 citations)

12. Tinetti ME, Baker DI, McAvay G, et al. A multifactorial intervention to reduce the risk of falling among elderly people living in the community. $N$ Engl J Med. 1994;331(13):821-27. (2611 citations)

13. Podsiadlo D, Richardson S. The Timed "Up \& Go": a test of basic functional mobility for frail elderly persons. J Am Geriatr Soc. 1991;39(2):142-48. (11076 citations)

14. Beers MH, Ouslander JG, Rollingher I, et al. Explicit criteria for determining inappropriate medication use in nursing home residents. Arch Intern Med. 1991;151(9):1825-32. (1673 citations)

15. Rockwood K, Fox RA, Stolee P, et al. Frailty in elderly people: an evolving concept. CMAJ. 1994;150(4):489-95. (674 citations)

16. Warren MW. Care of the chronic aged sick. Lancet. 1946;247(6406):841-43. (200 citations)

17. Report (1947) of the Committee on the Care and Treatment of the Elderly and Infirm. BMJ. 1(4511 Suppl. 2215):133-40. (No citations)

18. Katz S, Ford AB, Moskowitz EW, et al. Studies of illness in the aged. The Index of ADL: a standardized measure of biological and psychosocial function. JAMA. 1963;185(12):914-19. (10807 citations)
19. Lawton MP, Brody EM. Assessment of older people: selfmaintaining and instrumental activities of daily living. Gerontologist. 1969;9(3 Pt.1):179-86. (15339 citations)

20. Brown AS, Brummel-Smith K, Bugess L, et al. National Institutes of Health Consensus Development Conference Statement: geriatric assessment methods for clinical decision-making. $\mathrm{JAm}$ Geriatr Soc. 1988;36(4):342-47. (55 citations)

21. Creditor MC. Hazards of hospitalization of the elderly. Ann Intern Med. 1993;118(3):219-23. (1450 citations)

22. Landefeld CS, Palmer RM, Kresevic DM, et al. A randomized trial of care in a hospital medical unit especially designed to improve the functional outcomes of acutely ill older patients. N Engl J Med. 1995;332(20):1338-44. (898 citations)

23. Isaacs $B$, Livingstone $M$, Neville $Y$. Survival of the unfittest-a study of geriatric patients in Glasgow. London, UK: Routledge \& Kegan Paul; 1972. (206 citations)

24. Fries JF. Aging, natural death, and the compression of morbidity. N Engl J Med. 1980;303(3):130-35. (4446 citations)

25. Katz S, Branch LG, Branson MH, et al. Active life expectancy. N Engl J Med. 1983;309(20):1218-24. (1083 citations)

26. Rowe JW, Kahn RL. Human aging: usual and successful. Science. 1987;237(4811):143-49. (3837 citations)

27. Mossey JM, Shapiro E. Self-rated health: a predictor of mortality among the elderly. Am J Public Health. 1982;72(8):800-08. (2515 citations)

28. Ware JE, Sherbourne CD. The MOS 36-item short-form health survey (SF-36). I. Conceptual framework and item selection. Med Care. 1992;30(6):473-83. (34901 citations)

29. Molloy DW, Guyatt GH. A comprehensive health care directive in a home for the aged. CMAJ. 1991;145(4):307-11. (63 citations)

30. Leacock S. Three score and ten. The Spectator. 1940 Jan 19; 164(5821):72-73.

31. Russell B. How to grow old. In: Portraits from memory and other essays. London, UK: George Allen \& Unwin; 1956. p. 50-52.

32. Cowley M. View from 80. Harmondsworth, UK: Penguin Books; 1982.

33. Folstein MF, Folstein SE, McHugh PR. "Mini-mental state": a practical method for grading the cognitive state of patients for the clinician. J Psychiatr Res. 1975;12(3):189-98. (83636 citations)

34. Nasreddine ZS, Phillips NA, Bédirian V, et al. The Montreal Cognitive Assessment, MoCA: a brief screening tool for mild cognitive impairment. J Am Geriatr Soc. 2005;53(4):695-99. (10433 citations)

35. Cole MG, Primeau FJ, Bailey RF, et al. Systematic intervention for elderly inpatients with delirium: a randomized trial. CMAJ. 1994;151(7):965-70. (171 citations)

36. Inouye SK, Bogardus ST, Charpentier PA, et al. A multicomponent intervention to prevent delirium in hospitalized older patients. N Engl J Med. 1999;340(9):669-76. (2795 citations)

37. McCusker J, Cole M, Dendukuri N, et al. Delirium in older medical inpatients and subsequent cognitive and functional status: a prospective study. CMAJ. 2001;165(5):575-83. (489 citations)

38. Petersen RC, Smith GE, Waring SC, et al. Mild cognitive impairment: clinical characterization and outcome. Arch Neurol. 1999;56(3):303-08. (9405 citations)

39. Summers WK, Majovski LV, Marsh GM, et al. Oral tetrahydroaminoacridine in long-term treatment of senile dementia, Alzheimer type. $N$ Engl J Med. 1986;315(20):1241-45. (1391 citations)

40. Sheldon JH. On the natural history of falls in old age. $B M J$. 1960;2(5214):1685-90. (384 citations) 


\section{HOGAN: PERSONAL TOP TEN GERIATRIC PAPERS}

41. Isaacs B, Livingstone M, Nelville Y. The fall of Mrs McGoldrick. In: Isaacs B, Livingstone M, Neville Y, editors. Survival of the unfittest - a study of geriatric patients in Glasgow. London, UK: Routledge \& Kegan Paul; 1972. p. 1-3. (206 citations)

42. Tinetti ME. Performance-oriented assessment of mobility problems in elderly patients. J Am Geriatr Soc. 1986;34(2):119-26. (3537 citations)

43. Tinetti ME, Speechley M, Ginter SF. Risk factors for falls among elderly persons living in the community. $N$ Engl J Med. 1988;319(26):1701-07. (7124 citations)

44. Studenski S, Perera S, Wallace D, et al. Physical performance measures in the clinical setting. J Am Geriatr Soc. 2003; 51(3):314-22. (1063 citations)

45. Osler W. Recent advances in medicine. Science. 1891; 17(425):170-71.

46. Holmes HM, Hayley DC, Alexander GC, et al. Reconsidering medication appropriateness for patients late in life. Arch Intern Med. 2006;166(6):605-09. (397 citations)

47. Fiatarone MA, O'Neill EF, Ryan ND, et al. Exercise training and nutritional supplementation for physical frailty in very elderly people. N Engl J Med. 1994;330(25):1769-75. (3356 citations)

48. Fried LP, Tangen CM, Walston J, et al. Frailty in older adults: evidence for a phenotype. J Gerontol A Biol Sci Med Sci. 2001;56(3):M146-57. (13034 citations)

49. Mitnitski AB, Mogilner AJ, Rockwood K. Accumulation of deficits as a proxy measure of aging. Sci World J. 2001;1:323-36. (1062 citations)

50. Nascher IL. Geriatrics. N Y Med J. 1909;90:358-59.

51. St. John PD, Hogan DB. The relevance of Marjory Warren's writings today. Gerontologist. 2014;54(1):21-29.

52. Gurland BJ, Maurer MS. Life and works of Sidney Katz, MD: a life marked by fundamental discovery. JAMDA. 2012;13(9):764-65.

53. Saxon W. Dr. M. Powell Lawton, 77, expert on the elderly. New York Times. 2001 Feb 5: B6.

54. Olszewski TM. Between bench and bedside: building clinical consensus at the NIH, 1977-2013. J Hist Med Allied Sci. 2018;73(4):464-500.

55. Solomon DH. Geriatric assessment: methods for clinical decision making. JAMA. 1988;259(16):2450-52.

56. Epstein AM, Hall JA, Besdine R, et al. The emergence of geriatric assessment units: the "new technology of geriatrics". Ann Intern Med. 1987;106(2):299-303.

57. Ellis G, Gardner M, Tsiachristas A, et al. Comprehensive geriatric assessment for older adults admitted to hospital. Cochrane Database Syst Rev. 2017;9:CD006211.

58. Butler RN. Why survive? Being old in America. New York, NY: Harper \& Row; 1975.

59. Gondek D, Bann D, Ning K, Grundy E, et al. Post-war (19462017) population health change in the United Kingdom: a systematic review. PLoS One. 2019;14(7):e0218991.

60. Cowley M: View from 80. Penguin Books (Harmondsworth, Middlesex, England), 1982. p. ix.

61. Leacock S. My remarkable uncle and other sketches. New York, NY: Dodd, Mead and Company Inc.; 1942.

62. Cowley M. Being old old. New York Times. 1985 May 26: SM58.

63. Mazhari S. The 100 top-cited articles published in psychiatric journals. J Psychiatr Pract. 2013;19(4):327-38.

64. Heinik J. V.A. Kral and the origins of benign senescent forgetfulness and mild cognitive impairment. Int Psychogeriatr. 2010;22(3):395-402.
65. Kass J. Profile - Sharon Inouye. Lancet Psychiat. 2014;1(4):263.

66. Wei LA, Fearing MA, Sternberg EJ, et al. The Confusion Assessment Method (CAM): a systematic review of current usage. $J$ Am Geriatr Soc. 2008;56(5):823-30.

67. Inouye SK, Viscoli CM, Horwitz RI, et al: A Predictive Model for Delirium in Hospitalized Elderly Medical Patients Based on Admission Characteristics. Ann Intern Med 1993, 119(6): 474-481.

68. Inouye SK, Charpentier PA. Precipitating factors for delirium in hospitalized elderly persons: predictive model and interrelationship with baseline vulnerability. JAMA. 1996;275(11):852-57.

69. Bradley EH, Schlesinger M, Webster TR, et al. Translating research into clinical practice: making change happen. $J \mathrm{Am}$ Geriatr Soc. 2004;52(11):1875-82.

70. Inouye SK, Baker DI, Fugal P, et al. Dissemination of the Hospital Elder Life Program: implementation, adaptation, and successes. J Am Geriatr Soc. 2006;54(10):1492-99.

71. Segelken HR. Robert Katzman, Alzheimer's activist, dies at 82 [Obituary]. New York Times. 2008 Sept 23. Accessed 21/01/2020 at - https://www.nytimes.com/2008/09/24/us/24katzman.html

72. Katzman R, Terry R, Bick K. Alzheimer's disease: senile dementia and related disorders (Aging Series). New York, NY: Raven Press; 1978.

73. Alzheimer's Association. 2019 Alzheimer's facts and figures. Alzheimers Dement. 2019;15(3):321-87.

74. Boller F, Bick K, Duyckaerts C. They have shaped Alzheimer disease: the protagonists, well known and less well known. Cortex. 2007;43(4):565-69.

75. Fox P. From senility to Alzheimer's disease: the rise of the alzheimer's disease movement. The Milbank Q. 1989; 67(1):58-102.

76. Drachman DA, Leavitt J. Human memory and the cholinergic system: a relationship to aging? Arch Neurol. 1974; 30(2):113-21.

77. Katzman R, Bick K. Alzheimer disease-the changing view. San Diego, CA: Academic Press; 2000. p. 167-210.

78. Francis PT, Palmer AM, Snape M, et al. The cholinergic hypothesis of Alzheimer's disease: a review of progress. J Neurol Neurosurg Psychiatry. 1999;66(2):137-47.

79. Comfort A. Cholinesterase inhibition in treatment of Alzheimer's disease. Lancet. 1978;311(8065):659-60.

80. Davis KL, Mohs RC. Cholinergic drugs in Alzheimer's disease. N Engl J Med. 1986;315(20):1286-87.

81. Oral tetrahydroaminoacridine in the treatment of senile dementia, Alzheimer's type (letter to the editor). $N$ Engl J Med. 1987;316(25):1603-05.

82. Relman AS. Tacrine as a treatment for Alzheimer's dementia—editor's note [Special Report]. N Engl J Med. 1991;324(5): 349-52.

83. Karlawish JHT. The search for a coherent language: the science and politics of drug testing and approval. In: Kapp MB, editor. Ethics, law, and aging review: 8:39-56. New York, NY: Springer Publishing Co.; 2002.

84. Arie T. Professor Bernard Isaacs (1924-1995) Post 2. London, UK: British Geriatrics Society. Accessed January 20, 2020 at https:// www.bgs.org.uk/professor-bernard-isaacs-1924-1995-post-2

85. Nisbet NH. Some practical considerations in the care of the old. Lancet. 1953;261(6752):184-90.

86. Gryfe CI, Amies A, Ashley MJ. A longitudinal study of falls in an elderly population: I. Incidence and morbidity. Age Ageing. 1977;6(4):201-10. 


\section{HOGAN: PERSONAL TOP TEN GERIATRIC PAPERS}

87. Ashley MJ, Gryfe CI, Amies A. A longitudinal study of falls in an elderly population: II. Some circumstances of falling. Age Ageing. 1977;6(4):211-20.

88. Baker DI, King MB, Fortinsky RH, et al. Dissemination of an evidence-based multicomponent fall risk-assessment and -management strategy throughout a geographic area. $J \mathrm{Am}$ Geriatr Soc. 2005;53(4):675-80.

89. Tinetti ME, Baker DI, King M, et al. Effect of dissemination of evidence in reducing injuries from falls. $N$ Engl J Med. 2008;359(3):252-61.

90. Lord SR, Menz HB, Tiedemann A. A physiological profile approach to falls risk assessment and prevention. Physical Ther. 2003;83(3):237-52.

91. Mathias S, Nayak US, Isaacs B. Balance in elderly patients: the "get up and go" test. Arch Phys Med Rehabil. 1986;67(6): 387-89.

92. Cushing H. The life of Sir William Osler, Volume 1. Oxford, UK: Clarendon Press; 1925. p. 342-43.

93. Lau DT. Standing on the shoulders of Mark H. Beers: more than a giant in geriatric medicine. Clin Ther. 2009;31(4):822-24.

94. O'Mahony D. STOPP/START criteria for potentially inappropriate medications/potential prescribing omissions in older people: origin and progress. Expert Rev Clin Pharmacol. 2020;13(1):15-22.

95. Pazan F, Gercke Y, Weiss C, Wehling M; FORTA raters: The U.S.-FORTA (Fit fOR The Aged) list: consensus validation of a clinical tool to improve drug therapy in older adults [published online ahead of print, 2019 Sep 18; S1525-8610(19)30583-3]. J Am Med Dir Assoc. 2020;21(3):489.

96. Bain KT, Holmes HM, Beers MH, et al. Discontinuing medications: a novel approach for revising the prescribing stage of the medication-use process. J Am Geriatr Soc. 2008; 56(10):1946-52.

97. Frank C, Weir E. Deprescribing for older patients. CMAJ. 2014;186(18):1369-76.

98. Gijzel SMW, Whitson HE, van de Leemput I, et al. Resilience in clinical care: getting a grip on the recovery potential of older adults. J Am Geriatr Soc. 2019;67(12):2650-57.

Correspondence to: David B. Hogan, MD, FRCPC, HSC-3330 Hospital Dr. NW, Calgary, AB T2N 4N1, Canada

E-mail: dhogan@ucalgary.ca 